\title{
Benthic communities of Russian Arctic Seas under radioactive pollution condition
}

\author{
V. Galtsova and D. Alexeev \\ Russian State Hydrometeorological University, 195196, Malookhtinsky Pr. 98, \\ Saint-Petersburg, Russian Federation \\ e-mail: gavalentina@hotmail.com; dkalexeev@gmail.com
}

\begin{abstract}
One of the primary goals was to estimate the impact of the concentration of radioactive caesium on meio- and macrobenthic organisms in Barents and Kara Seas. It is determine that macrobenthos is more inert component, less subjected to the influence of this factor. Meiobenthos reacts to the radioactive pollution by the change of the taxonomic diversity and quantitative characteristics faster then.
\end{abstract}

\section{INTRODUCTION}

Radioactive pollution of marine ecosystems is one of the most dangerous anthropogenic impacts on the biota. The objects of this study were bottom ecosystems of Barents and Kara Sea. Different areas of Russian Arctic seas were exposed to significant emission of radioactive nuclides. The main aim of our study was to evaluate the impact of a radioactive contamination on macro- and meiobenthic communities. The special attention was given to the meiobenthic organisms - the small bottom animals inhabiting a small space between grains of the sediment.

\section{MATERIALS AND METHODS}

The study was based on the material collected by expeditions of Zoological Institute RAS, VNIIOkeangeologia, Murmansk Marine Biological Institute around the Murmanskoe shoal. Samples of meiobenthos were collected on cruises of research vessel "Geologist Fersman" in August-September, 1993 around Novaya Zemlya, and hydrographic ship "Captain Smirnitsky" in August-October 1995 on the international expedition "Seas and estuary of the Russian Arctic-95" [1-7] (Fig. 1).

The collection and the treatment of samples were carried out by using standard methods. To obtain the quantity of information about taxonomic diversity, the Shannon-Weawer index [8] showing the degree of habitat saturation by various taxonomic groups was calculated:

$$
H=-\sum_{i=1}^{n} P_{i} \log _{2} P_{i} .
$$

$P_{i}=\mathrm{Ni} / \mathrm{N}-$ part of $\ll \mathrm{i} »$ taxonomic group in total density.

\section{RESULTS AND DISCUSSIONS}

The radioactive pollution is the result of various reasons: a waste discharge of industrial waters, radioactive waste disposal and breakdowns on atomic submarines.

The area of the Murmansk shoal where the nuclear submarine "Kursk" has sunk on the ridge of

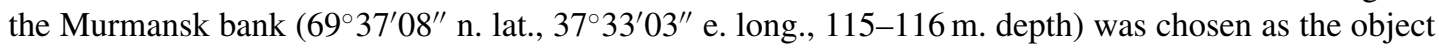




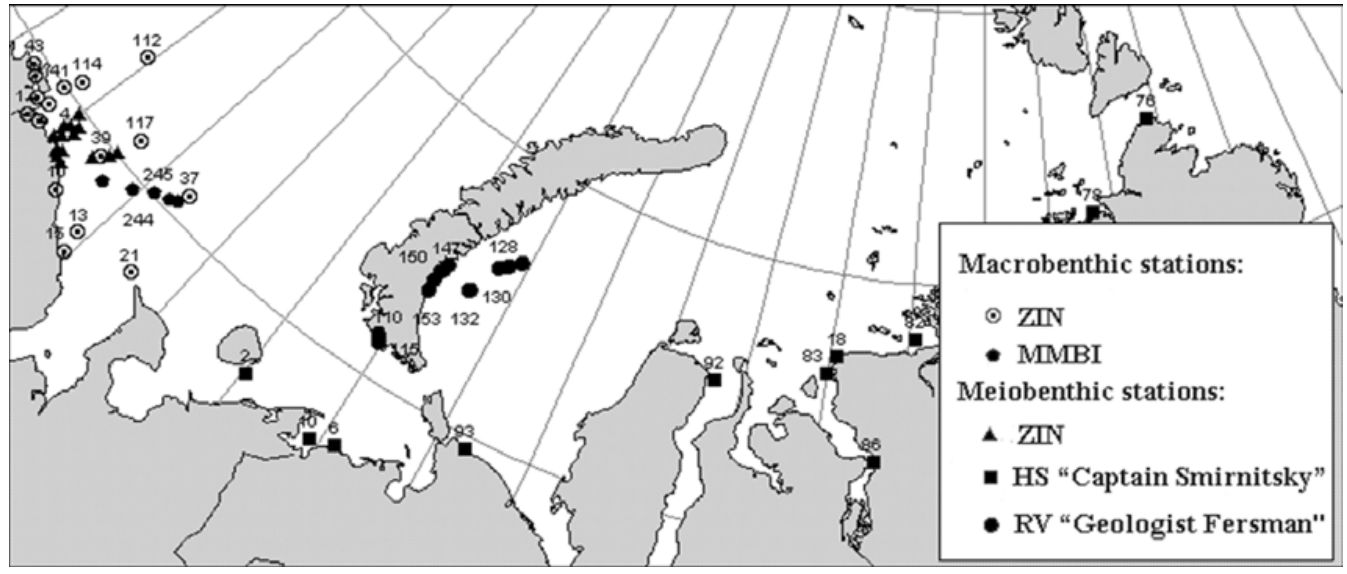

Figure 1. The location of macro- and meiobenthic stations on the Murmanskoe shoal, Novaya Zemlya and the shelf zone of Barents and Kara Seas.

of the study of macro- and meiobenthic communities structure. The species diversity of macrobenthos sites under study was rather high. The taxonomic list of macrobenthos of Murmansk shoal includes 192 species of animals. The difference on the quantitative characteristics (on the biomass) in various macrobenthic communities composed several orders of magnitudes. On an average, the biomass equals tens to hundreds grams on $1 \mathrm{~m}^{2}$. The values of the Shannon-Weawer index varied from 0,87 to 2,32.

In the structure of macrobenthos of the coast slope (by species diversity) the first place belonged to Cirripedia and Echinodermata (sea-urchins and basket stars). The banks population was characterised by Echinodermata domination (sea-urchins, holothurians and starfishes on the Murmanskaya bank) and by a considerable quantity of Bivalvia. The taxonomic structure of invertebrates of depressions and troughs showed a considerable quantity of Echinodermata (starfishes in the Kaninsky trench and the North-Djupet trench) and Bivalvia. The trophic structure of the biocenoses of macrobenthos was composed of fixed sestonophages, mobile sestonophages, gathering detritophages, deposit-feeders and carnivorous. In the biogeographical structure boreal-arctic species predominated, then were arctic and boreal organisms. The spatial distribution of the macrobenthos in the shelf zone of the Murmanskoe shoal had a mosaic structure.

One of the tasks of this work was to study a possible local influence of sources of radioactive pollution on bottom communities. Relative to macrobenthos, on the basis of the analysis of references $[9,10]$ it is possible to assume the following. Macrobenthic communities are the most inert component of marine bottom ecosystems. The lifetime of the primary macrobenthic organisms is measured by several years. Therefore, this category of benthos cannot instantly react to an increase of the radioactivity level of environment by a change in its structure, including species diversity. It is possible to expect with the big share of probability, the substantial growth of radionuclide concentration in bottom organisms, especially in mobile and fixed sestonophages, detritophages and deposit-feeders.

Relative to meiobenthos, at the present moment there are few studies, concerning the influence of the radioactive pollution on meiofauna. To resolve this problem, the additional material collected during the cruise of research vessel "Geologist Fersman" around Novaya Zemlya in a Chernaya Inlet (31-87 m. depth), in Stepovogo and Abrosimova Inlets (44-74m. depth) and around the Novozemelskaya Depression (333-403 m. depth), and also - during the cruise of hydrographic ship "Captain Smirnitsky" in 1995 in the shelf zone of Barents and Kara Seas, including Obskaya Inlet and Yeniseiskiy Gulf was used.

Meiobenthos includes the forms which remain in dimensional category $0.1-3.0 \mathrm{~mm}$ during entire life cycle, and also immature individuals of macrobenthos. According to this in the limits meiobenthos 
is divided in permanent (eumeiobenthos) and temporary (pseudomeiobenthos) components. The following groups of eumeiobenthos were found in Barents and Kara seas: Foraminifera, Turbellaria, Gnathostomulida, Nematoda, Kinorhyncha, Cnidaria, Priapulida, Ostracoda, Harpacticoida, Entoprocta, Tardigrada; and pseudomeiobenthos: Nemertini, Oligochaeta, Polychaeta, Tanaidacea, Amphipoda, Gastropoda, Bivalvia, Asteroidea, Isopoda. The values of the Shannon - Weaver index varied from 0.40 to 2.41 , the average value was 1.50 (Fig. 2).

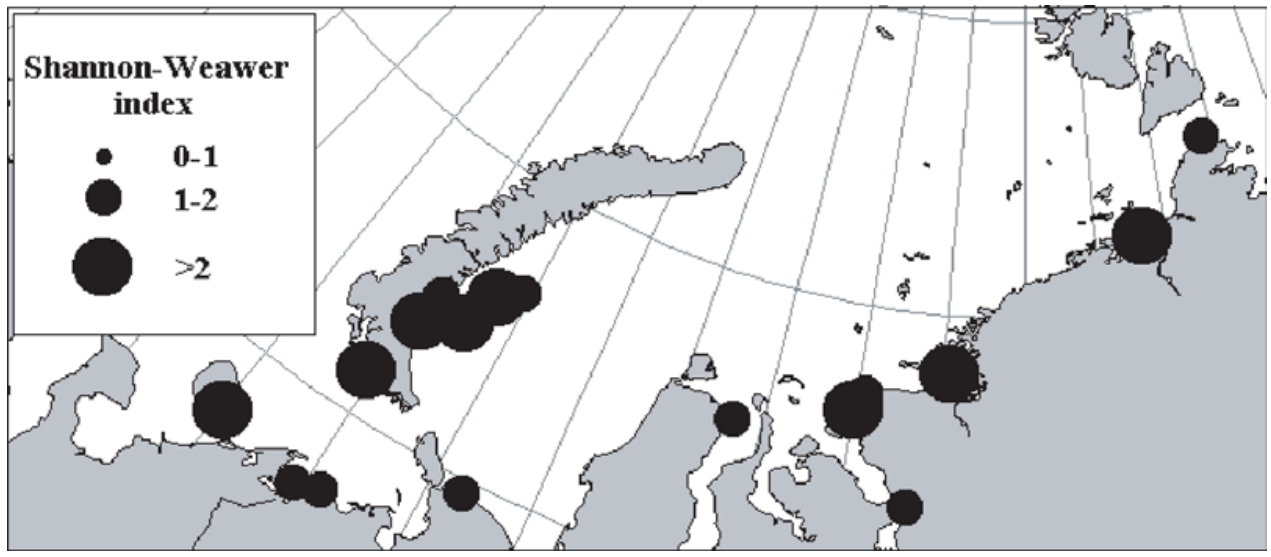

Figure 2. Spatial distribution of the meiobenthos diversity in various areas of Barents and Kara Seas.

The quantitative characteristics (the density and the biomass) of meiobenthos, its subdivisions and separate groups changed in the limits of 2-3 orders of magnitudes. The minimum density of meiobenthic animals was 15 thousand ind $/ \mathrm{m}^{2}$, the maximum density -5426 thousand ind $/ \mathrm{m}^{2}$ (Fig. 3). The highest value of the biomass of meiobenthos was $47327 \mathrm{mg} / \mathrm{m}^{2}$, the smallest one $-833 \mathrm{mg} / \mathrm{m}^{2}$. The eumeiobenthos density varied from 40 to $100 \%$, averaging $89.5 \%$ of the density of the total meiobenthos. Nematodes usually were the dominant group, harpacticoids and foraminifers - subdominant.

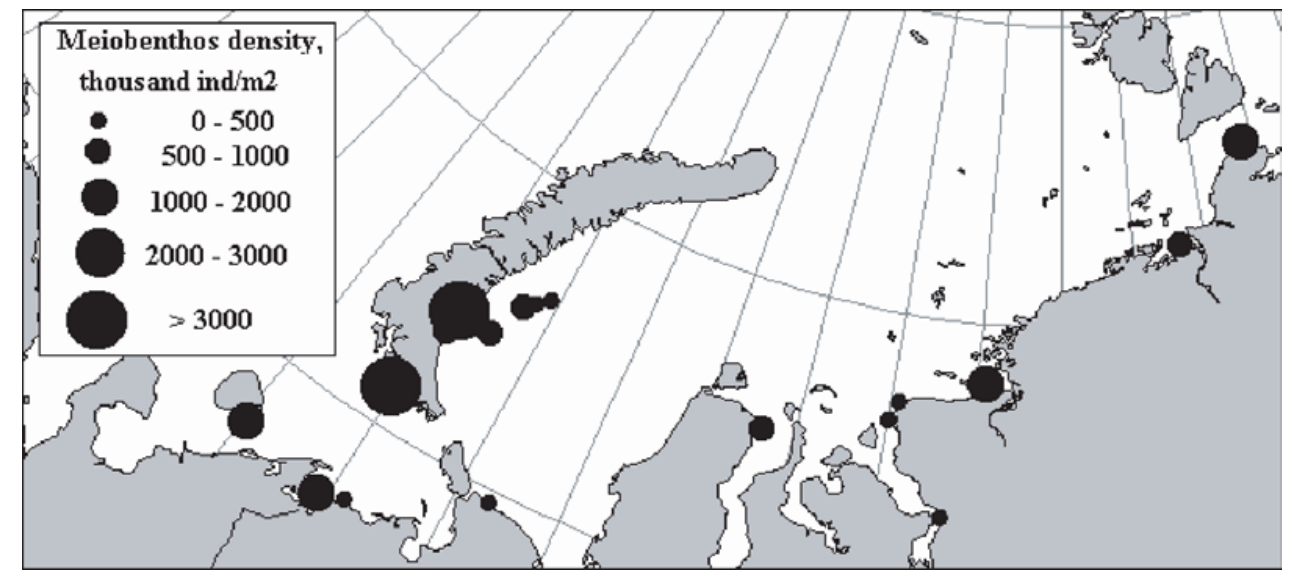

Figure 3. Spatial distribution of the meiobenthos density in various areas of Barents and Kara Seas.

The Chernaya Inlet is the place of the first underwater, atmospheric and underground tests of the nuclear weapon. The Abrosimova and Stepovogo Inlets on the east coast of archipelago became a place of underwater storage of barges, ships and containers with radioactive waste. The Obskaya Inlet and 
the Yeniseiskiy Gulf were exposed by radioactive nuclides with river flows for a long time. This kind of influence resulted in a high radiocaesium concentration in bottom sediment (more than $100 \mathrm{~Bq} / \mathrm{kg}$, at averages of value of $0-10 \mathrm{~Bq} / \mathrm{kg}$ ) (Fig. 4).

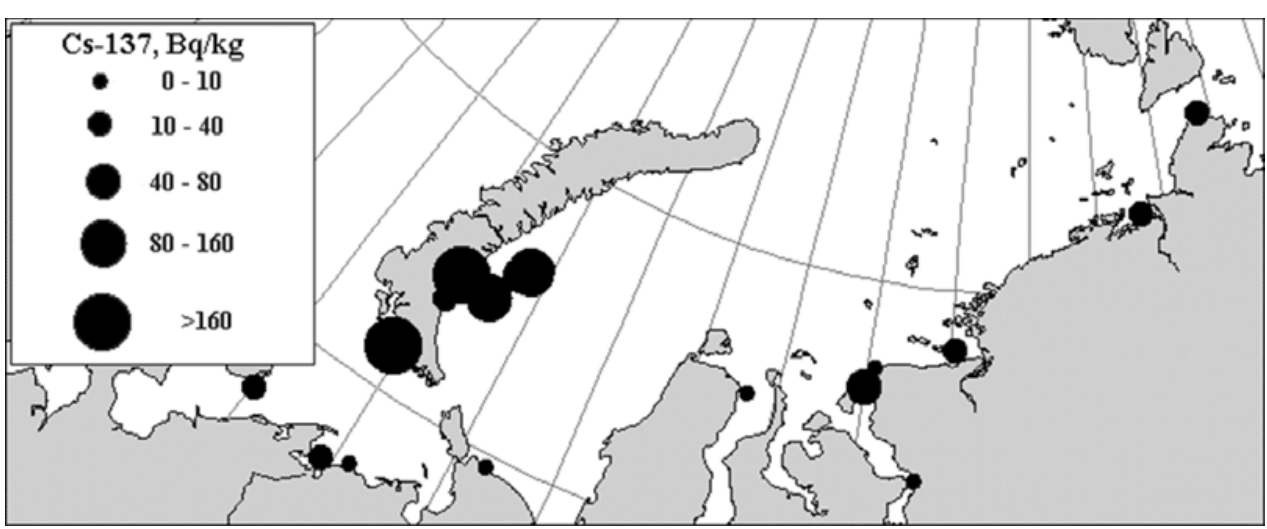

Figure 4. Concentration of radiocaesium in bottom sediments in various areas of Barents and Kara Seas $(\mathrm{Bq} / \mathrm{kg})$.

Comparison of the Chernaya Inlet meiobenthic communities with those of neighboring areas off the Novaya Zemlya Souther Island showed the communities of the open sea turned out to be more abundant. In other words, averaged characteristic of the open see differed from those of the inlet [11]: 1) meiobenthos density here was three times lower and biomass - five times lower then Chernaya Inlet; 2) community structure was quite different; 3 ) communities variability turned out to be smaller.

One of the primary goals was to estimate the impact of the concentration of radioactive caesium on meiobenthic organisms. To establish dependences, the Pearson correlation coefficient was calculated between the radiocaesium concentration, the meiobenthic density and the Shannon-Weawer index. The value of the correlation coefficient shows significant relationship between these parameters (Table 1).

Table 1. Value of the Pearson correlation coefficient, showing relationship between the radiocaesium concentration, the meiobenthic density and the Shannon-Weawer index in Barents and Kara sea.

\begin{tabular}{|l|c|c|c|c|c|c|}
\hline \multirow{2}{*}{ Taxon } & $\begin{array}{c}\text { Correlation } \\
\text { coefficient }\end{array}$ & Student's test & $\begin{array}{c}\text { Number of } \\
\text { degrees of } \\
\text { freedom }\end{array}$ & \multirow{2}{*}{$\begin{array}{c}\text { Reliability of } \\
\text { estimate }\end{array}$} \\
\cline { 2 - 6 } & $\mathrm{r}$ & $\sigma_{\mathrm{r}}$ & $\mathrm{t}$ & $\mathrm{t}_{\mathrm{st}}$ & $\mathrm{v}$ & \\
\hline \multicolumn{7}{|c|}{ Novaya Zemlya, 1993 year } \\
\hline Shannon-Weawer index & 0,41 & 0,21 & 1,92 & 1,75 & 15 & Reliable positive \\
\hline Meiobenthos & $-0,43$ & 0,21 & 2,08 & 1,75 & 15 & Reliable negative \\
\hline \multicolumn{7}{|c|}{ Shelf zone of Barents and Kara seas, 1995 year } \\
\hline Shannon-Weawer index & 0,54 & 0,18 & 2,99 & 1,81 & 10 & Reliable positive \\
\hline Meiobenthos & 0,63 & 0,16 & 4,02 & 1,81 & 10 & Reliable positive \\
\hline
\end{tabular}

The increase of radiocaesium concentration results in increase of the taxonomic diversity (Fig. 5). However, the influence of the content of caesium-137 on quantitative characteristics is not univocal (Fig. 6). Most likely, the small concentrations of ${ }^{137} \mathrm{Cs}$ have no influence, or can even lead to insignificant increase of the density of small bottom fauna. However, reaching some threshold concentration $(20 \mathrm{Bk} / \mathrm{kg})$ changes in meiobenthic communities start to have an irreversible character that leads to the reduction of their density. 


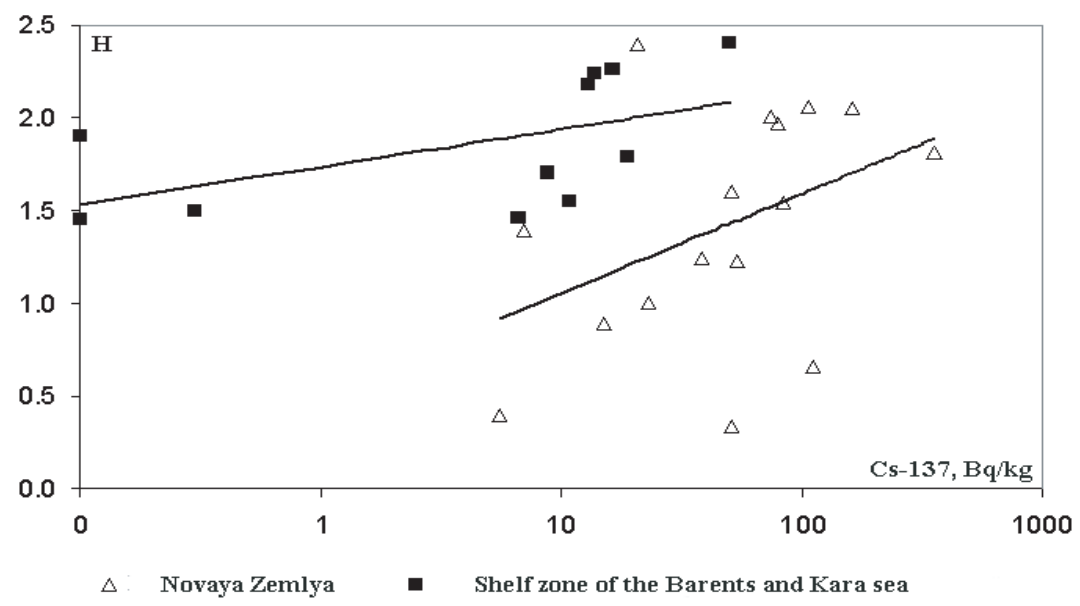

Figure 5. The correlation between diversity of meiobenthos and concentration of radiocaesium in hydrobiological station in Barents and Kara Seas.

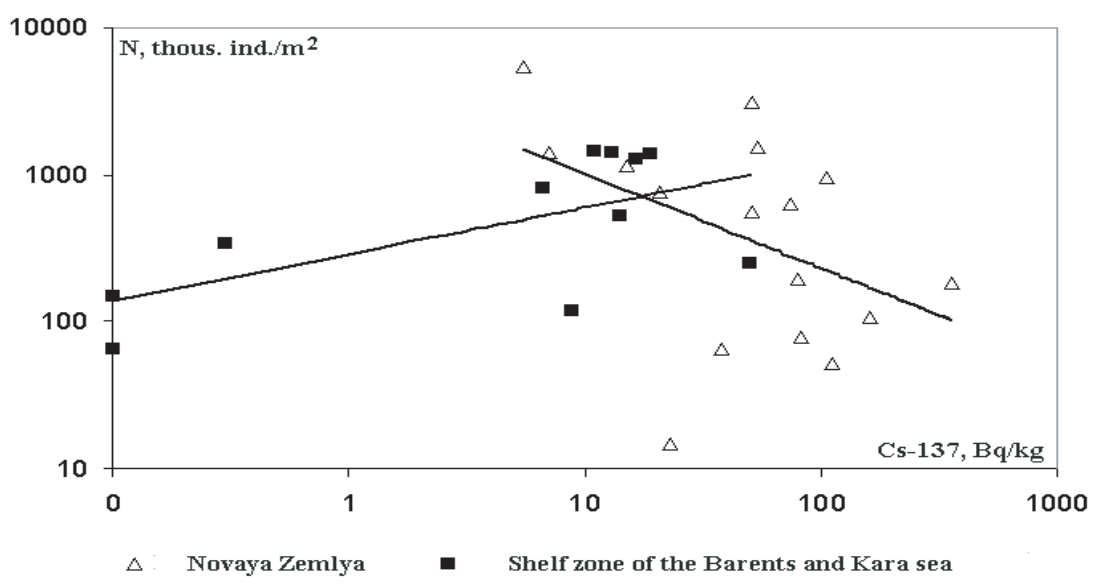

Figure 6. The correlation between density of meiobenthos and concentration of radiocaesium in hydrobiological station in Barents and Kara Seas.

\section{CONCLUSION}

It is possible to conclude that meiobenthos reacts to the radioactive pollution by the change of the taxonomic diversity and quantitative characteristics faster then macrobenthos, which is more inert component, less subjected to the influence of this factor. Large bottom organisms accumulate radioactive nuclides in cells and tissues for long period of time.

\section{References}

[1] Golikov A.N., Anisimova N.A., Golikov A.A., Denisenko N.V., Kaptilina T.V., Menshutkin V.V., Menshutkina T.V., Novikov O.K. and Panteleeva N.N. 1993. Bottom communities and biocenose of Yarnishnay inlet of the Barents sea and their seasonal trend.Apatity: 1-56.

[2] Galtsova V.V. and Kulangieva L.V. 1996. Meiobenthos of Yarnishnay inlet of the Barents sea. Russian Journal of Marine Biology. 22, 1: 3-9. 
[3] Pogrebov V.B., Galtsova V.V. and Fokin S.I. 1995a. Meio- and macrobenthos of Prilazlomnoe oilfield: estimation of state with a view the elocogical monitoring. In: Development of Russian arctic seas. St. Petersburg: 367-369.

[4] Pogrebov V.B., Galtsova V.V. and Fokin S.I. 1995b. Meio- and macrobenthos of Prilazlomnoe oilfield with a view the elocogical monitoring. Vestnik SPbGU. 3, 4 (24): 9-19.

[5] Frolova E.A. 2000. Landscape observation and zoobenthos structure of south part of Novozemelskaya bank and Novaya Zemlya profile - Dal'nie Zelency village (48th passages materials of RV «Dal'nie Zelency», 1988). Up-to-date benthos of the Barents and Kara SEAS.Apatity: 23-43.

[6] Galtsova V.V., Kulangieva L.V. and Pogrebov V.B. 2004a. Meiobenthos communities of Barents and Kara Seas under conditions of radioactive pollution. In: Ecological and hydrometeorological problems of the big cities and industrial zones. St. Petersburg: 82-89.

[7] Galtsova V.V., Kulangieva L.V. and Alekseev D.K. 2004b. Estimation of an ecological condition of a shelf zone of the Arctic seas under anthropogenic impact. In: Ecological and hydrometeorological problems of the big cities and industrial zones. St. Petersburg: 43-48.

[8] Shannon C. E. and Weaver W. 1963. The mathematical theory of communication. Urbana: 1-177.

[9] Ilus E., Sjoblom K.-L. and Ikaheimonen T. K. 1993. Monitoring of radionuclides in the Baltic Sea in 1989-1990. STUK-A. 105: 35.

[10] Kuznetsov A.P., Dando P., Shmelev I.P., Denisenko S.G., Efimov B.V., Demidov A.M. and Shunko V.M. 1995. Radioactive nuclides in bottom fauna around area of sunked NS "Komsomolec" (the Norwegian Sea). Izvestiya RAN. Biological series. 4: 467-471.

[11] Galtsova V.V., Kulangieva L.V. and Pogrebov V.B. 2004c. Meiobenthos from areas of former nuclear range and places of a burial of radioactive waste products around of archipelago Novaya Zemlya (Barents and Kara Seas). Russian Journal of Marine Biology.30, 4: 263-271. 